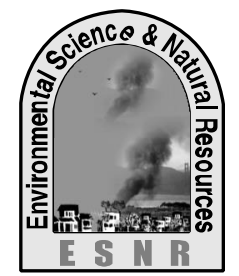

\title{
Solar Power Irrigation towards Saving Energy for Agricultural Production: A Feasibility Study
}

\author{
M. N. H. Khan*, M. H. Khan and M. F. H. Khan \\ Centre for Irrigation and Water Resource Management \\ Rural Development Academy, Bogra-5842 \\ *Corresponding author: hasannakibk@gmail.com
}

\section{Abstract}

Renewable energy presents a better alternative to fossil fuels with greener impact on environment. The present study was conducted to evaluate the opportunities and viabilities of using direct solar power as a source of green energy in irrigation to make the rice farming profitable one. In the present study 24 Polycrystalline of each 270 watt solar panels were installed in scattered manner at $\angle 24^{0}$ with a height of $7 \mathrm{ft}$. A D.C submersible pump of $3.5 \mathrm{KW}$ was set up with a $90 \mathrm{ft}$ depth deep-tubewell (DTW). In Bangladesh sunshine hour varies from 10 to 13 hours and solar radiation varies from 3.5 to $6.0 \mathrm{KW} \mathrm{hm} \mathrm{hm}^{-2}$ $\mathrm{day}^{-1}$ through out year. By direct solar power, average running time of pump was 08 hours per day and full flow of water discharge was 4.5 hours per day. Average water discharge was 40710 liter per hour and total water discharge was $310 \mathrm{~m}^{3}$ per day. By the system a scheme of 15 acres of land was irrigated where 1.3 acre per day. The financial and economic value of BCR was 1.43 and 1.5, respectively; and the financial and economic value of IRR was $68 \%$ and $98 \%$, respectively.

Key words: Irrigation, Renewable energy, Solar power

\section{Introduction}

Bangladesh has been facing severe electricity crisis, energy sources for irrigation pumping, such as fossil fuels, are subsidized by the government. Renewable energy presents a better alternative to fossil fuels with greener impact on environment. Considering the present state of power generation short fall and scarcity of natural gas, Government has set a target to meet $5 \%$ of total power demand by 2015 and $10 \%$ of total power demand by 2020 from renewable energy sources on the above ground (GoB, 2011). During the Boro season, rice field in Bangladesh is irrigated by 1.33 million different types of water pumps, among which $87 \%$ are diesel operated requiring 800 million liter diesel per year (Biswas and Hossain, 2013). Pumps run by electricity needs 700 to $800 \mathrm{MW}$ of power and cover $30 \%$ of total irrigated land (Kabir and Chowdhury, 2012). The introduction of solar power irrigation system will save $750 \mathrm{MW}$ power and 800 million liter diesel every year if the conventional power and diesel run irrigation pumps are converted into solar power.

The application of solar energy for irrigation is much interest for researchers around the world. Use of solar energy for irrigation in Bangladesh has suggested by Mahbub et al. (2012) and this solar powered drip irrigation scheme would enhance food security Burney et al. (2010). Abundant sunshine in Bangladesh is the blessing of nature which can be exploited to increase agricultural productivity in multiple ways. Direct solar powered irrigation in agriculture can cut a huge expenditure of the government on account of procuring diesel at high cost. Therefore, the present study was conducted to evaluate the opportunities and viabilities of using direct solar power as a source of green energy in irrigation to make the rice farming profitable one.

\section{Materials and Methods}

Different tools were applied to evaluate and demonstrate the performance of direct solar power irrigation system. To accomplish the study different instruments, regular observation, literature survey etc. techniques were applied.

\section{Study area}

The study was conducted at the demonstration farm of Rural Development Academy (RDA), Bogra that located $24^{\circ} 42^{\prime} 18^{\prime \prime}$ north latitude and $89^{\circ} 234^{\prime \prime}$ east longitude.

\section{Instruments used}

In our study total number of $24^{\circ}$ solar panels was set up where each panelô capacity was 270 watt, and the total capacity of these panels was $6.48 \mathrm{KW}$ (Table 1). Panels were installed in scattered manner at $\angle 24^{\circ}$ with a height of $7 \mathrm{ft}$. Depth of DTW was $90 \mathrm{ft}$ where housing pipe was $40 \mathrm{ft}$. With the DTW a D. C submersible pump of $3.5 \mathrm{KW}$ was set up (Table 1).

\section{Data collection}

Total time of pump run, voltage and ampere loaded by the pump, static and pumping water level (in feet), water flow (liter hour ${ }^{-1}$ ), time of full flow (hour), total water discharge (in $\mathrm{m}^{3} \mathrm{day}^{-1}$ ), total land area coverage $\left(\right.$ acre day $^{-1}$ ) by irrigation etc. data were recorded in daily basis from 31 March 2013 to 29 June 2013 with one hour interval time period from 07.00 am to $06.00 \mathrm{pm}$.

\section{Data analysis}

Data were processed using MS Excel (Microsoft Excel) and analyzed as per objectives by tabular and graphical methods. The economic and financial analysis i.e. Net Present Value (NPV), Benefit-cost Ratio (BCR) and Internal Rate of Return (IRR) were calculated as cost benefit analysis. 
Table 1. Technical information of solar irrigation system

\begin{tabular}{|l|l|}
\hline \multicolumn{1}{|c|}{ Instruments } & \multicolumn{1}{c|}{ Description } \\
\hline Solar panel & Polycrystalline $(270 \mathrm{Wp} ; 18.20 \%$ efficiency) \\
\hline Panel capacity & $24 \mathrm{X} 270 \mathrm{Wp}=6480 \mathrm{Watt}(6.48 \mathrm{~kW})$ \\
\hline Placement of panel & $\begin{array}{l}\text { Panels are installed in scattered manner } \\
\text { North-south }=17 \mathrm{ft} ; \text { East-west }=14 \mathrm{ft} \\
\text { Panel height }=7 \mathrm{ft}, \text { at } \angle 24^{0}\end{array}$ \\
\hline Deep tube-well (Borehole) & $\begin{array}{l}\text { Depth- } 90 \mathrm{ft} \text {; Housing pipe-40 ft, dia-14 inch; Strainer- } 40 \mathrm{ft}, \\
\text { dia- 40inch; Bail plug- } 10 \mathrm{ft} \text {, dia- } 14 \text { inch }\end{array}$ \\
\hline Pump & D.C submersible pump $(\mathrm{H}=8-16 \mathrm{~m} ; \mathrm{Q}=35-60 \mathrm{~m} 3 / \mathrm{hr} ; 3.5 \mathrm{~kW}) ;$ \\
\hline Groundwater level & $\begin{array}{l}\text { Static water level }(\mathrm{SWL})=30 \mathrm{ft} ; \text { Pumping water level }(\mathrm{PWL})= \\
37 \mathrm{ft} \text {; Drawdown=7 ft. }\end{array}$ \\
\hline Charge regulator and panel board & Over load/voltage, low voltage protection and dry protection \\
\hline Irrigation area & $15 \mathrm{acre}$ \\
\hline
\end{tabular}

\section{Results and Discussion}

Opportunity for solar power

Geographically Bangladesh is a subtropical which located between $20.30^{\circ}$ to $26.38^{\circ} \mathrm{N}$ latitudes and $88.04^{\circ}$ to $92.44^{\circ} \mathrm{E}$ longitudes where sunshine does not fluctuate too much like high latitudes countries. As a subtropical country, Bangladesh is the ideal location for solar energy utilization where $70 \%$ of sunlight dropped annually (Rahman et al., 2013). The total sunshine hour in the country lies 10 to 13 hours per day throughout the year (Shariar et al., 2011) shown in Fig. 1. It is a great opportunity that sunlight remains almost same throughout the year. Solar radiation in Bangladesh also varies from season to season. Bangladesh receives the maximum amount of solar radiation on April and minimum on November-December-January (Anam and Bustam, 2011). Annual average solar radiation varies from 3.5 to $6.0 \mathrm{Kwhm}^{-2} \mathrm{day}^{-1}$ and in our study period on April 4.5 to $6.5 \mathrm{KWhm}^{-2} \mathrm{day}^{-1}$, on May 4.5 to $6.0 \mathrm{KWhm}^{-2} \mathrm{day}^{-1}$ and on June 3.5 to 5.5 $\mathrm{KWhm}^{-2}$ day $^{-1}$ (NREL, 2010). Sunshine hour and solar radiation does not fluctuate too much in Bangladesh, it fluctuates very little and therefore, solar power as well as direct solar powered irrigation would be very much feasible in Bangladesh.

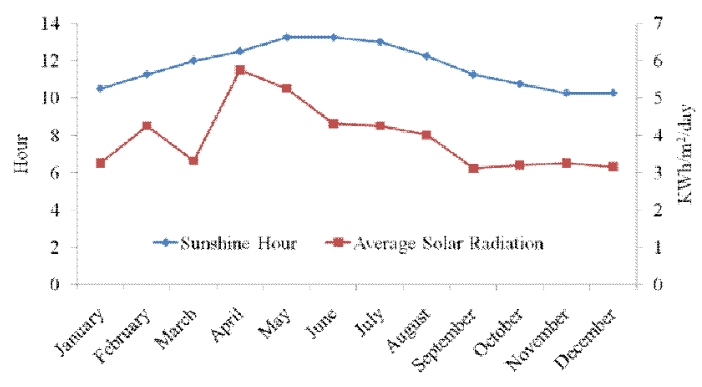

Fig. 1. Sunshine hour and solar radiation throughout the year in Bangladesh

Capacity of the solar panel: volt and ampere loaded by pump

Considering the opportunity of direct solar power irrigation, a solar plant as well as deep tube well (DTW) was set up at RDA demonstration farm. In our study total number of 24 solar panels was set up where each panelôs capacity was 270 watt, and the total capacity of these panels was $6.48 \mathrm{KW}$ (Table 1). A $3.2 \mathrm{KW}$ submersible pump was set up at the DTW with direct connection to the solar power. Loaded volt by the pump varies from $160 \mathrm{~V}$ to $272 \mathrm{~V}$ and ampere varies from 7.76 to 12.68 (Fig. 2 ). The average loaded volt and ampere was $220.88 \mathrm{~V}$ and 10.5 ampere, respectively. In a cloudy or rainy weather lower the solar intensity of sunlight as a result lower the production of voltage as well as ampere by the solar panel.

\section{Pumping time and water discharge}

In the study, pump ran up to ten (10) hours per day and few days it did not run due to unfavorable weather condition as rainfall and the average running time was eight (08) hours (Fig. 3). Full flow of water discharged six (06) hours in maximum, one (01) hour in minimum and average 4.5 hours on a day of pump ran (Fig. 3). For the full flow of water discharge pump had to load maximum voltage, for maximum voltage solar panel of PV cell need to absorbed higher intensity of sunlight. A cloudy weather hampers absorption of higher intensity of sunlight. As a result the times of full flow varies as well as lower down. Water discharge varies from 27202 to 48397 liter per hour of a day and average water discharge was 40710 liter per hour (Fig. 3). 


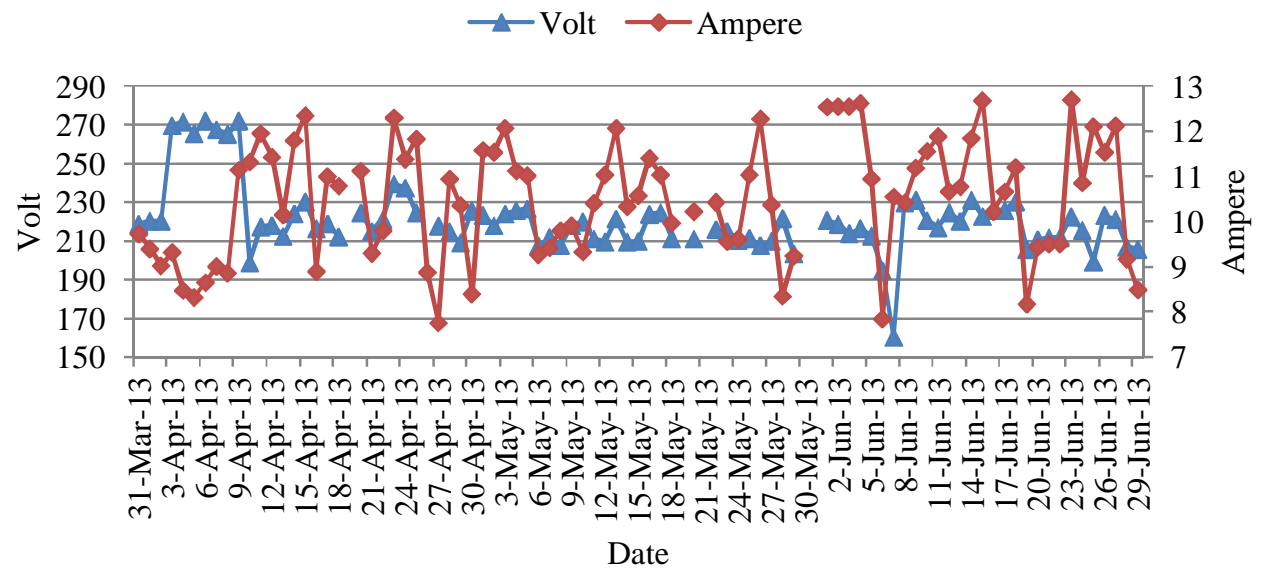

Fig. 2. Loaded volt and Ampere by the pump from solar panel

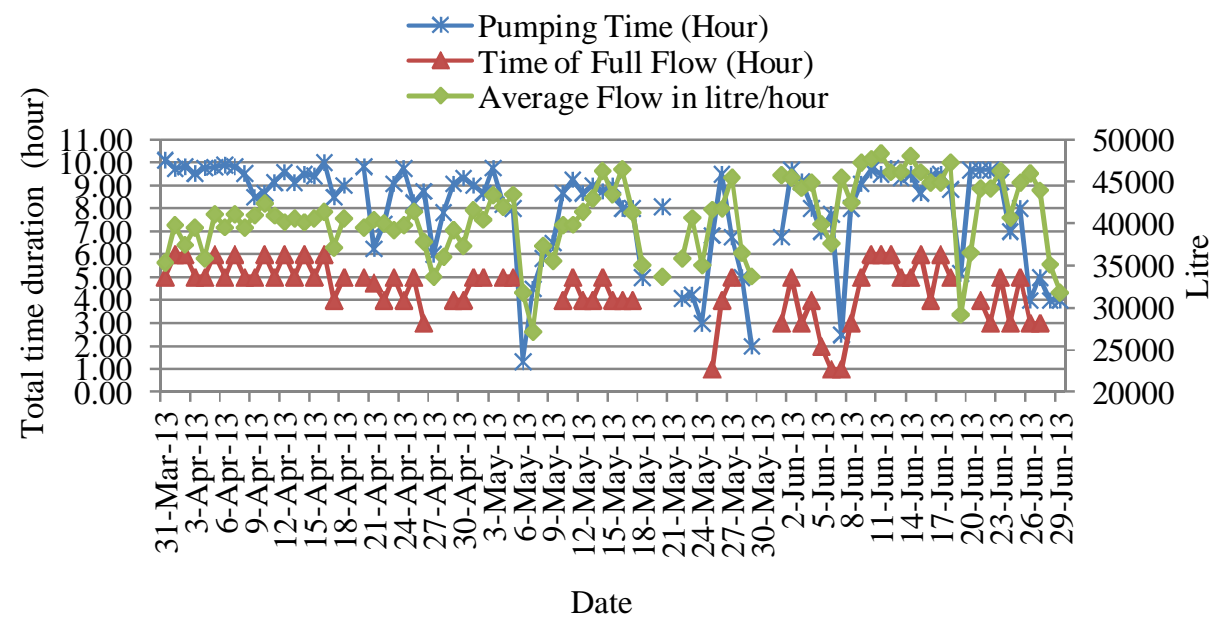

Fig. 3. Total pumping time, total time of full flow and average water flow per hour

\section{Total water discharge and irrigated land area}

Total water discharge varies from $96 \mathrm{~m}^{3}$ to $477 \mathrm{~m}^{3}$ per day and average discharge was $310.08 \mathrm{~m}^{3}$ (Figure 4). Through this discharged water 0.2 to 2.21 acre of land could irrigated and its average was 1.3 acre (Figure 4). Total discharge of water

*-Total Flow $(\mathrm{m} 3) \multimap$ Total Area Coverage (Acre)

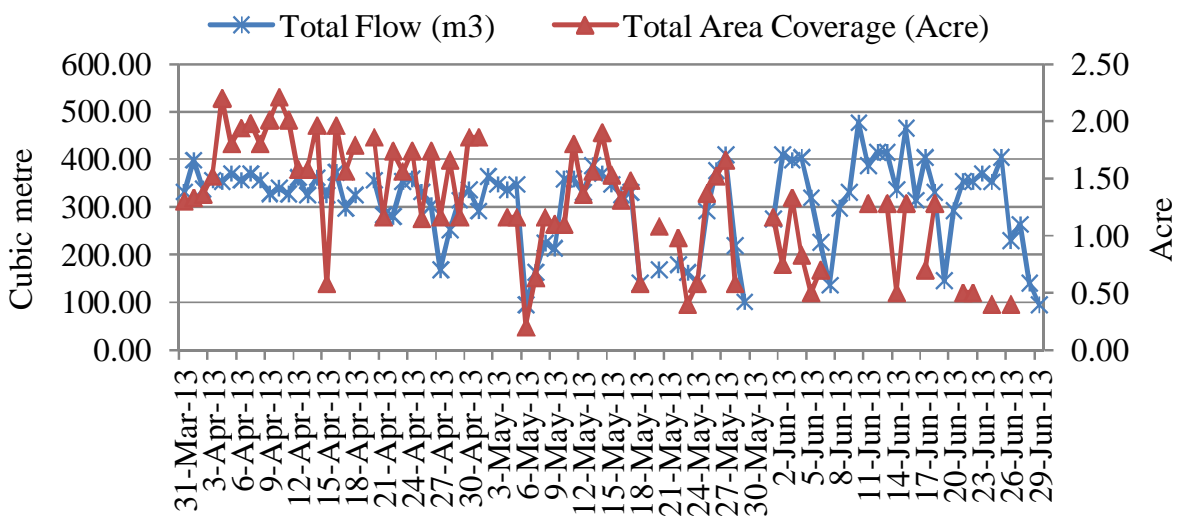

Date

Fig. 4. Total water discharge and irrigated land area depends on total run time of pump as well as full flow of water. Average 1.3 acre of land can irrigated per day from this system, the solar powered irrigation, with free of cost. 


\section{Cost benefit analysis}

Total installation cost of the system was US $\$ 18600$ only. For benefit, saving cost for fuel (diesel or electricity), irrigation charge for rice and vegetable cultivation were considered; environmental benefit did not considered here. We assumed the economic project life is 25 years and the salvage value is $10 \%$ of the total investment and also assumed here the lower discount rate is $15 \%$. The NPV for financial and economic value was US\$ 25200 and US\$ 28500 respectively. The financial and economic value of BCR was 1.43 and 1.51, respectively. The financial and economic value of IRR was $68 \%$ and $98 \%$, respectively.

\section{References}

Anam, K. and Bustam, H. A. 2011. Power Crisis \& Its Solution through Renewable Energy in Bangladeshò, Cyber Journals: Multidisciplinary Journals in Science \& Technology, Journal of Selected Areas in Renewable and Sustainable Energy (JRSE).

Biswas, H. and Hossain, F. 2013. Solar Pump: A Possible Solution of Irrigation and Electric Power Crisis of Bangladesh. International Journal of Computer Applications, 62(16):1-5

Burney, J.; Woltering, L.; Burke, M.; Naylor, R. and Pastmak, D. 2010. Solar-powered drip irrigation enhances food security in the Sundano-Sahel. Proceedings of National Academy of Sciences of United States of America, pp. 1-6.

Government of Bangladesh (GoB). 2011. SIXTH FIVE YEAR PLAN (FY2011-FY2015): Accelerating Growth and Reducing Poverty, General Economics Division, Planning Commission, Ministry of Planning, Government of the Peopleâs Republic of Bangladesh.

\section{Conclusions}

As a sub-tropical country, Bangladesh is suitable place for direct solar powered irrigation. Although, the installment cost of solar systems is very much costly, but once installed it can give service up to 20-25 years with proper maintenance. By the system, $6.48 \mathrm{~kW}$ solar panel, a land scheme of 15 acres irrigated in a season at free of cost, without electricity or diesel. The direct solar powered irrigation would be very much feasible and effective for the remote areas of the subtropical as well as low latitudesô countries in terms of crop production as well as reduce the cost of electricity. It would also be applicable to save energy as well as reduce $\mathrm{CO}_{2}$.

Kabir, S. M. L. and Chowdhury, A. H. 2012. A Low Cost Multiple Motor Switched PV Powered Irrigation System, Journal of Electrical Engineering, 38 (2):16-21.

Mahbub, M. Z.; Shahriar, M. M. S.; Hossain, M. I.; Islam, M. W. and Rahman, M. S. 2012, Solar Energy Utilizing Irrigation System for the Rural Areas of Bangladesh. Global Journal of Science Frontier Research (D), XII (II):9-17.

NREL (National Renewable Energy Laboratory). 2010. Available at http://www.nrel.gov/gis/ images/ swera/ bangladesh/ retrieved 05/09/ 2013.

Rahman, M. S.; Saha, S. K.; Khan, M. R. H.; Habiba, U. and Chowdhury, S. M. H. 2013. Present Situation of Renewable Energy in Bangladesh: Renewable Energy Resources Existing in Bangladesh. Global Journal of Researches in Engineering Electrical and Electronics Engineering, 13 (5):1-7.

Shariar, K. F.; Ovy, E. G. and Hossainy, K. T. A. 2011. ñClosed Environment Design of Solar Collector Trough using lenss and reflectorsò, World Renewable Energy Congress, Sweden. 